\title{
PEMBERIAN REMISI KEPADA PELAKU TINDAK PIDANA NARKOTIKA PERSPEKTIF HUKUM PIDANA ISLAM
}

\author{
Ivvany Ningtyas Seily \\ \begin{tabular}{r|l} 
Rohmah & Jl. Hasanuddin Gg. 03 Celep Selatan \\
seily.cute28@gmail.com & Sidoarjo
\end{tabular}
}

Abstract: Punishment remission in Sidoarjo correction facility is granted to nearly all inmates with conditions set out by regulations. It is granted in many forms; general remission, special remission, additional remission, and decade remission. Remission for drug-related inmates is announced during ceremony of Indonesia's independence declaration in Sidaorjo's main square. Drug-related inmates gain their remission for good conduct in a sense that they repent from their past wrong doings. Remission in Islamic penal law is called takhfif al-uqûbah (punishment leniency).

Keywords: Remission, drug inmates, correctional facility.

Abstrak: Pemberian remisi bagi pelaku tindak pidana narkotika di Lembaga Pemasyarakatan Sidoarjo diberikan dengan beberapa syarat yang telah ditentukan oleh peraturan-peraturan yang ada. Remisi diberikan dengan beberapa jenis, yaitu remisi umum, remisi khusus, remisi tambahan dan juga remisi dasawarsa. Remisi diberikan kepada pelaku tindak pidana narkotika dengan cara mengumumkan pada saat upacara hari Kemerdekaan Negara Republik Indonesia di pendopo Sidoarjo. Remisi dalam hukum pidana Islam disebut juga dengan takhfif al-uqûbah (keringanan hukuman), remisi diberikan kepada narapidana narkotika karena itu adalah hak bagi setiap narapidana yang telah memenuhi syarat pemberian remisi, dan dalam hal ini setiap narapidana yang telah berkelakuan baik atau dengan kata lain bila narapidana narkotika telah menyesal atau bertaubat, maka narapidana narkotika berhak mendapatkan sesuatu yang harus diterima sebagi hak warga binaan pemasyarakatan.

Kata Kunci: Remisi, Narapidana Narkotika, Lembaga Pemasyarakatan Sidoarjo. 


\section{Pendahuluan}

Kejahatan sedang marak terjadi di masyarakat, baik kejahatan atas jiwa atau kejahatan yang bukan jiwa. Salah satu kejahatan tersebut adalah kejahatan yang merugikan dirinya sendiri atau merusak diri dan masa depan diri sendiri yaitu narkotika yang telah banyak merusak generasi muda di negara kita ini, bahaya narkoba tidak mengurangi antusias masyarakat untuk mengkonsumsinya.

Perusak generasi muda pada zaman sekarang adalah narkoba, narkoba sudah tidak asing lagi untuk didengar di masyarakat. Narkoba yaitu narkotika dan obat-obatan berbahaya atau narkotika dan obatobatan terlarang, sedangkan narkotika adalah zat atau obat yang berasal dari tanaman atau non tanaman baik sintetis maupun semi sintetis yang dapat menyebabkan penurunan atau perubahan kesadaran, hilangnya rasa, mengurangi sampai menghilangkan rasa nyeri, dan dapat menimbulkan ketergantungan. ${ }^{1}$

Narkoba sudah ada sejak zaman dahulu, namun narkoba pertama kali digunakan untuk kepentingan pengobatan dan menolong orang sakit. Sejak zaman prasejarah, manusia sudah mengenal zat psikoaktif berupa dedaunan, buah-buahan, akar-akaran dan bunga dari berbagai jenis tanaman yang sudah lama diketahui manusia purba akan efek farmatologinya. Sejarah mencatat, ganja sudah digunakan orang sejak tahun $2700 \mathrm{SM}^{2}$

Pada zaman sekarang narkoba telah merajai gaya hidup masyarakat. Di Indonesia khususnya, banyak masyarakat yang menggunakan bahkan mengedarkan narkoba, meskipun banyak pula pasal-pasal yang mengancam para pengguna dan pengedar narkoba, seperti contoh pasal 112 Undang-undang nomor 35 tahun 2009 tentang narkotika yang memberikan ancaman pidana empat tahun penjara bagi orang yang tanpa hak melawan hukum menggunakan, menyimpan, menguasai atau menyediakan narkotika. ${ }^{3}$ Namun tetap tidak ada rasa takut bagi mereka para pengguna narkoba tersebut.

Sangat disayangkan, warga negara bahkan para kaum muda sebagai aset negara terjerumus kepada narkoba yang merusak kehidupannya. Jika dilihat dari penjelasan di atas, narkoba mempunyai efek dapat

\footnotetext{
${ }^{1}$ M. Marwan dan Jimmy P, Kamus Hukum, (Surabaya: Reality Publisher, 2009), 447.

${ }^{2}$ Nurul Irfan dan Musyarofah, Figh Jinayah, (Jakarta: Pena Grafika, 2013), 175.

${ }^{3}$ Undang-undang nomor 35 tahun 2009 tentang Narkotika.
} 
menghilangkan rasa bahkan membuat lupa. Terkadang masyarakat pecandu narkoba menggunakan barang terlarang tersebut dikarenakan banyak masalah atau pengaruh dari teman. Untuk mendapatkan obat terlarang tersebut, para pecandu pertama diberi secara cuma-cuma oleh teman atau orang di sekitar yang lebih awal menggunakan atau para pengedar narkoba. Setelah pecandu narkoba merasakan efeknya pastilah pecandu mulai mengkonsumsi narkoba dengan membeli dari orang yang menawarinya. Ketika pecandu sudah mengkonsumsi narkoba tersebut bukan hanya satu kejahatan yang dibuatnya, bisa jadi melakukan kejahatan lainnya seperti mencuri, membunuh dan lain sebagainya.

Narkoba tidak dijelaskan secara gamblang dalam hukum pidana Islam, namun narkoba dapat disamakan dengan khamr yaitu sesuatu yang memabukkan, dan hukuman bagi peminum atau pengguna khamr dalam Islam akan dikenakan had atau hudûd. Telah dijelaskan dalam al-Qur'an surat al-Baqarah ayat 219 yang berbunyi:

Wahai orang-orang yang beriman, sesungguhnya minuman keras, berjudi, (berkurban untuk) berhala, dan mengundi nasib dengan anak panah, adalah perbuatan keji dan termasuk perbuatan setan. Maka jauhilah (perbuatan-perbuatan) itu agar kamu beruntung. ${ }^{4}$

Narkotika telah lama dikenal umat manusia. Tapi sebenarnya lebih banyak madharatnya dari pada manfaatnya. Untuk itu, hampir semua agama besar melarang umat manusia untuk mengkonsumsi narkotika dan minuman keras (dalam bentuk yang lebih luas lagi adalah narkoba). ${ }^{5}$

Dari uraian di atas diketahui bahwa narkoba bisa membahayakan diri sendiri dan masyarakat. Narkoba membawa banyak madharat dan tidak ada manfaatnya. Beberapa jenis narkoba hanya ada manfaatnya jika dipakai untuk keperluan ilmu pengetahuan, pengobatan, dan medis. Syaratnya harus dalam pengawasan ahlinya yang berkompeten secara ketat dan terarah. Pemakaiannya pun sangat terbatas dan menurut petunjuk dokter. Di luar itu semua, maka narkoba bisa merusak fisik dan psikis, raga dan jiwa. Narkoba juga sangat dekat dengan dunia kejahatan dan kekerasan.

Para pemakai narkoba sering mengalami keterasingan dari dirinya sendiri, dan menderita depresi berat. Para pemakai nerkoba seringkali mengalami perubahan pribadi yang baik menjadi buruk, dari pribadi yang

\footnotetext{
${ }^{4}$ Departemen Agama Rl, Al-Quran dan Terjemahannya, (Semarang: PT. Karya Toha Putra, 2002), 42.

${ }^{5}$ M. Arif Hakim, Bahaya Narkoba Alkohol, (Bandung: Nuansa, 2004), 87.
} 
sehat menjadi sakit. Narkoba memang seharusnya dijauhi karena lebih banyak madharatnya. Apabila memang pemakai narkoba tertangkap oleh penegak hukum seharusnya dia dihukum yang setimpal mengingat efek narkoba yang sangat membahayakan.

Meskipun pengguna narkoba telah dijatuhi hukuman, namun kebanyakan narapidana tidak jera dengan adanya hukuman tersebut karena dengan berkelakuan baik selama di dalam lembaga pemasyarakatan narapidana mendapatkan keringanan hukuman atau yang disebut dengan remisi.

Dengan adanya remisi narapidana dapat keringanan hukuman, dan dengan adanya pengurangan masa tahanan seperti kurang adanya efek jera karena dengan adanya hukuman tersebut narapidana dapat menyesali perbuatan yang telah dilakukan, kususnya pelaku tindak pidana narkotika, pelaku tindak pidana narkotika dijatuhi hukuman empat tahun penjara, dan menggunakan narkotika lebih dari empat tahun, dapat dilihat betapa tidak adanya efek jera bila pengguna narkotika mendapatkan remisi hanya dengan berkelakuan baik, bisa jadi para narapidana hanya sekedar menyesali kelakuannya untuk mendapatkan pengurangan masa tahanan, seharusnya dalam hal pemberian remisi harus lebih selektif dan bukan hanya sekedar dapat berkelaluan baik dalam lembaga pemasyarakatan.

Walaupun ada hak asasi manusia, pemberian remisi tersebut terlihat sangat kurang memberikan efek jera bagi pelaku tindak pidana narkotika, karena dalam pengurangan masa tahanan atau pemberian remisi dirasa kurang wajar karena dalam remisi terdapat remisi umum dan remisi khusus dimana pengurangan masa tahanan bukan hanya satu atau dua hari saja namun mencapai satu bulan bahkan lebih, dan dengan berkelakuan baik atau hanya sekedar sering adzan di mushola dan juga sekedar menang dalam perlombaan pada hari kemerdekaan di Lembaga Pemasyarakatan Sidoarjo.

Adanya suatu hukum itu karena adanya suatu peristiwa, maka dari itu dengan adanya hukum yang bertujuan sebagai pengontrol perilaku manusia, dan fungsi dari adanya hukuman yaitu untuk membuat pelaku menjadi jera dan menyesal akan perbuatannya, oleh karena itu adanya suatu hukuman yang berfungsi untuk memberikan efek jera maka pemberian remisi bukan sekedar diberikan kepada para narapidana, namun seharusnya juga harus ada syarat tertentu untuk mendapatkan remisi bagi narapidana. 
Dari latar belakang yang telah diuraikan diatas, yaitu mengenai pemberian remisi kepada pelaku tindak pidana narkotika, penulis tertarik untuk mengangkat permasalahan tersebut di Lembaga Pemasyarakatan Sidoarjo. Pemberian remisi kepada pelaku tindak pidana narkotika di Lembaga Pemasyarakatan Sidoarjo serta menurut hukum pidana Islam dalam penulisan ini, serta alasan pemberian remisi kepada pelaku tindak pidana narkotika.

\section{Pemberian Remisi di Lembaga Pemasyarakatan Sidoarjo}

Kata remisi berasal dari bahasa Inggris yaitu remission. Re yang berarti kembali dan mission yang berarti mengirim, mengutus. Remisi diartikan pengampunan atau pengurangan hukuman. Dari pengertian tersebut, remisi merupakan kata serapan yang diambil dari bahasa asing yang kemudian digunakan dalam pengistilahan hukum di Indonesia. ${ }^{6}$ Remisi adalah pengurangan masa pidana yang diberikan kepada narapidana dan anak pidana yang berkelakuan baik selama menjalani pidana. ${ }^{7}$ Menurut Kamus Besar Bahasa Indonesia, remisi adalah pengurangan hukuman yang diberikan kepada orang yang terhukum. ${ }^{8}$

Di Lembaga Pemasyarakatan Sidoarjo remisi diberikan dengan berbagai macam atau berbagai jenis yaitu:

a. Remisi umum yang diberikan pada hari kemerdekaan Republik Indonesia pada tanggal 17 Agustus, semua narapidana atau anak pidana yang telah memenuhi syarat pemberian remisi diberikan haknya untuk menerima remisi umum tersebut.

b. Remisi khusus yang diberikan kepada narapidana atau anak pidana yang telah memenuhi syarat pemberian remisi pada saat hari raya keagamaan.

c. Remisi tambahan diberikan kepada narapidana atau anak pidana yang telah memenuhi syarat pemberian remisi dan remisi tambahan ini diberikan kepada setiap pemuka di Lembaga Pemasyarakatan Sidoarjo.

d. Remisi dasawarsa diberikan kepada narapidana atau anak pidana yang telah memenuhi syarat pemberian remisi dan remisi dasawarsa diberikan setiap sepuluh tahun sekali.

\footnotetext{
${ }^{6}$ M. Fahmi Al-Amruzi, "Analisis Hukum Pemberian Remisi Terhadap Pelaku Tindak Pidana", Jurnal Darussalam, 2 (Desember 2014), 2.

${ }^{7}$ Keputusan Menteri Hukum dan Perundang-undangan RI Nomor M.09.HN.02.01 Tahun 1999.

8 Tim Penyusun Kamus Pusat Bahasa, Kamus Besar Bahasa Indonesia, (Jakarta: Balai Pustaka, 2005), 945.
} 
Adapun syarat pemberian remisi di Lembaga Pemasyarakatan Sidoarjo yaitu sebagaimana syarat pemberian remisi pada umumnya yaitu: a. Berkelakuan baik, yaitu narapidana yang telah menaati peraturan yang ada di dalam lapas dan juga tidak sedang dijatuhi hukuman disiplin yang dicatat dalam buku register $\mathrm{F}$ selama kurun waktu ditentukannya remisi. ${ }^{9}$ Berkelakuan baik bukan hanya dalam hal menaati peraturan namun berkelakuan baik juga dinilai dari perilaku atau tingkah laku narapidana selama menjalani masa pidananya, dan juga dapat dilihat dari perilaku sesama narapidana juga dalam hal ibadahnya, atau membantu petugas lapas dalam menjalankan tata tertib yang ada. Penilaian berperilaku baik adalah menjadi tanggung jawab pihak lapas, namun sangat sulit jika pihak lapas harus mengawasi satu persatu narapidana oleh karena itu dalam hal mengawasi tingkah laku dapat dilakukan juga oleh narapidana dengan narapidana lainnya.

b. Telah menjalani masa pidana lebih dari enam bulan. Mendapatkan remisi memang hak dari setiap narapidana atau anak pidana bukan dengan syarat berkelakuan baik saja namun seorang narapidana atau anak pidana harus telah menjalani masa pidananya selama enam bulan. Masa enam bulan tersebut digunakan untuk menilai kelakuan baiknya, dan juga masa enam bulan tersebut sebagai adaptasi seorang narapidana atau anak pidana yang baru saja mendapatkan hukuman. Dan dengan masa enam bulan tersebut seorang napi bisa menyesuaikan diri dan setelah itu dapat diketahui bagaimana sikap dan perilakunya, serta dapat menilai apakah sudah pantas mendapatkan remisi atau belum.

\section{Remisi menurut Hukum Pidana Islam}

Dalam hukum pidana Islam, syarat diberikannya keringanan hukuman juga dengan adanya sebuah penyesalan dan juga meminta maaf kepada korban atau yang disebut juga dengan taubat. Taubat menurut istilah para sufi adalah kembali kepada ketaatan dari perbuatan maksiat, kembali dari nafsu kepada haq (jalan kebenaran). Dalam kitab at-ta'rifāt dijelaskan bahwa taubat adalah kembali kepada Allah dengan melepaskan ikatan yang membungkus hati (mengekang) kemudian bangkit menuju (memenuhi) hak Rab (Tuhan). Sementara itu Zunnûn al-Misri membagi bahwa taubat orang awam dari dosa, taubat orang khusus dari kelalaian dan taubat para nabi ketika melihat kelemahannya dalam ibadah

\footnotetext{
${ }^{9}$ Keputusan Menteri Hukum dan Perundang-Undangan Republik Indonesia Nomor M.09.HN. 02.01 Tahun 1999.
} 
dibandingkan dengan keberhasilan yang dicapai. ${ }^{10}$ Bertaubat dari segala dosa dengan kembali kepada dzat yang gaib (metafisik), tobat dalam ilmu suluk merupakan tingkatan yang ada, karenanya, seorang salik (ahli suluk) tidak dapat dipisahkan. Dalam referensi lainnya mengatakan bahwa taubat adalah kembalinya seorang hamba kepada Allah dan uzlah (menjauhkan diri) dari jalan orang-orang yang dimurkai oleh Allah serta jalan orangorang sesat.

Syarat-syarat untuk taubat bergantung pada siapa yang menjadi korban kesalahan itu, dimana hal ini dikelompokkan menjadi tiga tingkatan: Pertama, bila kesalahan itu terhadap Allah swt, maka taubatnya dengan menyesali dosa-dosa yang diperbuat dan berjanji untuk tidak mengulanginya. Kedua, berdosa kepada Allah dan makhluk ciptaannya dengan berjanji untuk meninggalkan dosa-dosa itu dan menyesalinya. Ketiga, apabila dosanya berhubungan dengan hak orang lain, maka bagi orang yang bertaubat harus memperbaiki sesuatu yang rusak dan karena dirinya atau memohon kerelaan orang yang dia salahi.

Ada sebagian ulama yang berpendapat, bahwa jika orang yang sudah berjanji dengan taubatnya, tetapi mengulangi kembali dosa-dosanya, maka taubatnya yang terdahulu itu batal dan tidak sah. Jadi andaikata kesalahan yang diperbuat berhubungan dengan sesama manusia, maka taubatnya dengan meminta halal hak yang diambilnya, kemudian menyesali perbuatan tersebut dihadapan Allah, karena itu hak Allah. Taubat yang terlibat transaksi ilegal dan barang-barang yang diharamkan, seperti minuman keras dan saksi palsu karena upah, maka ulama masih berbeda pendapat tentang masalah tersebut.

Sekelompok ulama berpendapat, dia harus mengembalikan uang yang telah diterimanya kepada pemiliknya, sebab itu adalah hartanya yang sah. Sedangkan si penjual, maka dia telah mengambilnya melalui jalan yang tidak diperkenankan oleh syara', dan si pembeli, dengan mengeluarkan uangnya itu tidak memperoleh keuntungan secara halal.

Pendapat lain mengatakan bahwa taubatnya ialah dengan menyedekahkan uang hasil transaksi itu, dan tidak wajib baginya untuk mengembalikan kepada pemiliknya. Sebab hal itu tidak mungkin, karena oleh sang empunya akan digunakan untuk bermaksiat kepada Allah. Begitu juga taubat bagi orang yang hartanya bercampur dari sumber yang

\footnotetext{
${ }^{10}$ Septiawadi, "Tafsir Sufistik tentang Taubat dalam Al-Qur'an", Jurnal Studi Agama dan Pemikiran Islam, 2 (Desember, 2013), 3.
} 
halal dan haram, yakni dengan bersedekah kira-kira sebesar harta haram yang mencampuri hartanya, kemudian hendaknya dia membersihkan sisa hartanya dari perkara haram. ${ }^{11}$ atau juga bisa dengan taubatan nasuha.

Taubah Nashûhah atau taubat secara murni yaitu, membebaskannya dari segala kotoran, kekurangan dan kerusakan Imam Hasan al-Bashri berkata bahwa memurnikan taubat ialah dengan menyesali apa yang diperbuatnya di masa lalu dan bertekad untuk tidak mengulanginya. Al-Kalbi berkata, taubat adalah dengan beristighfar melalui lisannya, menyesali dengan hati dan berhenti berbuat dosa dengan raga. Sedangkan menurut Said bin al-Musayyib berkata, bahwa arti taubah nashûhah ialah bila engkau menasehati diri sendiri.

Dalam refrensi lain mengatakan bahwa taubah nashûhah yaitu meninggalkan semua dosa lalu menyesalinya, bertekad untuk tidak mengulanginya lagi, berusaha mengembalikan hak-hak kepada siapa saja yang sudah dizaliminya, dan berusaha memohon ampunan serta taubat kepada Allah mencari rahmatnya, berusaha menghindari siksa dan azab. ${ }^{12}$

Ibnu Qayyim berpendapat bahwa taubat yang murni mengandung tiga unsur yaitu: Pertama, taubat yang meliputi atas keseluruhan jenis dosa, tidak ada satu dosapun melainkan bertaubat karenanya. Kedua, membulatkan tekad dan bersungguh-sungguh dalam bertaubat, sehingga tidak ada keragu raguan dan menunda-nunda kesempatan bertaubat. Ketiga, menyucikan dari segala kekotoran dan hal-hal yang dapat mengurangi rasa keikhlasan, khauf kepada Allah dan menginginkan karunianya. Tidak seperti taubatnya orang yang ingin menjaga nama baik, mempertahankan kedudukan atau untuk menjaga martabat dan kekayaannya, atau demi popularitas. Supaya tidak mendapat gangguan dari orang-orang jahat, atau karena frustasi dan mungkin juga untuk tujuan-tujuan lain yang dapat mengurangi nilai dan kemurnian suatu taubat kepada Allah swt.

\section{Dasar Hukum Pemberian Remisi di Lembaga Pemasyarakatan Sidoarjo}

Pemberian remisi di Lembaga Pemasyarakatan Sidoarjo yaitu dengan cara diumumkan pada saat upacara Kemerdekaan Republik Indonesia tanggal 17 Agustus di pendopo Sidoarjo. Adapun dasar-dasar hukum pemberian remisi di Lembaga Pemasyarakatan Sidoarjo yaitu:

\footnotetext{
${ }^{11}$ Ahmad Faried, Menyucikan Jiwa,(Surabaya: Risalah Gusti, 2004), 168.

${ }^{12}$ Ahmad Farid, Taubat dalam Dosa,(Jakarta: Amzah, 2006), 30.
} 
a. Undang-undang Republik Indonesia nomor 12 Tahun 1995 tentang Pemasyarakatan.

b. Peraturan Pemerintah Republik Indonesia nomor 99 Tahun 2012 tentang perubahan atas Peraturan Pemerintah Republik Indonesia nomor 28 Tahun 2006 tentang Syarat dan Tata Cara Pelaksanaan Hak Warga Binaan Pemasyarakatan.

c. Keputusan Presiden nomor 174 Tahun 1999 tentang Remisi.

d. Keputusan Menteri kehakiman dan Hak Asasi Manusia Republik Indonesia nomor M.09.HN.02.01 Tahun 1999 tentang Pelaksanaan Keputusan Presiden Republik Indonesia nomor 174 tahun 1999 tentang Remisi.

e. Keputusan Menteri kehakiman dan Hak Asasi Manusia Republik Indonesia nomor M.HH-21.PK.01.01.02 Tahun 2015 tentang Penetapan Pengurangan Hukuman Secara Khusus Pada peringatan Tujuh Puluh Tahun Proklamasi Kemerdekaan Republik Indonesia.

f. Peraturan Menteri Hukum dan Ham RI Nomor 21 Tahun 2013 tentang Syarat dan Tata Cara Pemberian Remisi, Asimilasi, Cuti Mengunjungi Keluarga, Pembebasan Bersyarat, Cuti Menjelang Bebas dan Cuti bersyarat.

g. Surat Edaran Menteri Hukum dan HAM RI nomor M.HH04.PK.01.05.06 Tahun 2013 tentang Petunjuk Pelaksanaan Pemberlakuan Peraturan Pemerintah nomor 99 tahun 2012 tentang Syarat dan Tata Cara Pelaksanaan Hak Warga Binaan Pemasyarakatan.

h. Surat Edaran Direktur Jenderal Pemasyarakatan nomor PASPK.01.01.02-395 Tahun 2015 tanggal 13 Agustus 2015 tentang Penerbitan Surat Keputusan Remisi Dasawarsa Tahun 2015.

i. Surat Edaran Direktur Bina Narapidana dan Pelayanan Tahanan nomor PAS-PK.01.01.02-987 Tahun 2015 tanggal 14 Agustus 2015 tentang Penerbitan Surat Keputusan Remisi Dasawarsa Tahun 2015.

\section{Pemberian Remisi kepada Pelaku Tindak Pidana Narkotika di Lembaga Pemasyarakatan Sidoarjo}

Pemberian remisi pada umumnya berhak diterima oleh setiap narapidana atau anak pidana yang telah memenuhi syarat pemberian remisi, begitu pula bagi narapidana narkotika yang telah memenuhi syarat mendapatkan remisi pastilah mendapatkan remisi.

Dari hasil penelitian bahwa setiap pelaku tindak pidana narkotika mendapat remisi baik remisi umum atau remisi khusus, untuk remisi 
tambahan di LAPAS Sidoarjo sangat jarang diberikan remisi tambahan karena dalam hal ini remisi khusus diberikan kepada pemuka yang membantu kegiatan di LAPAS Sidoarjo.

Kebanyakan juga pelaku tindak pidana narkotika mendapat remisi dasawarsa sebesar 3 (tiga) bulan, dimana remisi dssawarsa itu diberikan setiap sepuluh tahun sekali, dan tentunya dengan syarat yang telah ditentukan pada peraturan yang sudah ada.

Namun kebanyakan juga pelaku tindak pidana narkotika tidak mengetahui bahwa mereka sudah mendapat remisi atau tidak, ada juga yang mengetahui telah mendapatkan remisi namun tidak mengetahui berapa besar remisi yang diterima.

Pelaku tindak pidana narkotika juga mendapatkan remisi umum atau khusus yang besarnya bermacam-macam tergantung lamanya pelaku tindak pidana narkotika yang menjalani masa pidananya.

Seperti halnya pada Keputusan Presiden nomor 174 tahun 1999 tentang remisi yang menjelaskan tentang besarnya remisi yaitu:

1) Pemberian remisi umum:

a. 1 (satu) bulan bagi Narapidana dan Anak Pidana yang telah menjalani pidana selama 6 (enam) sampai 12 (dua belas) bulan; dan

b. 2 (dua) bulan bagi Narapidana dan Anak Pidana yang telah menjalani pidana selama 12 (dua belas) bulan atau lebih.

2) Pemberian remisi umum diberikan sebagaimana berikut:

a. pada tahun pertama diberikan remisi sebagaimana dimaksud dalam ayat (1).

b. pada tahun kedua diberikan remisi 3 (tiga) bulan;

c. pada tahun ketiga diberikan remisi 4 (empat bulan;

d. pada tahun keempat dan kelima masing-masing diberikan remisi 5 (lima)bulan; dan

e. pada tahun keenam dan seterusnya diberikan remisi 6 (enam) bulan setiaptahun. ${ }^{13}$

3) Pemberian remisi khusus

a. 15 (lima belas) hari bagi Narapidana dan Anak Pidana yang telah menjalanipidana selama 6 (enam) sampai 12 (dua belas) bulan; dan

b. 1 (satu) bulan bagi Narapidana dan Anak Pidana yang telah menjalani pidana selama 12 (dua belas) bulan atau lebih.

4) Pemberian remisi khusus dilaksanakan sebagaimana berikut:

${ }^{13}$ |bid., pasal 4 
a. pada tahun pertama diberikan remisi sebagaimana dimaksud dalam ayat(1);

b. pada tahun kedua dan ketiga masing-masing diberikan remisi 1 (satu) bulan;

c. pada tahun keempat dan kelima masing-masing diberikan remisi 1 (satu )bulan 15 (lima belas) hari; dan

d. pada tahun keenam dan seterusnya diberikan remisi 2 (dua) bulan setiaptahunnya.

5) Pemberian remisi khusus

a. 1/2 (satu perdua) dari remisi umum yang diperoleh pada tahun yangbersangkutan bagi Narapidana dan Anak Pidana yang berbuat jasa kepadanegara atau melakukan perbuatan yang bermanfaat bagi negara ataukemanusiaan; dan

b. 1/3 (satu pertiga) dari remisi umum yang diperoleh pada tahun yang bersangkutan bagi Narapidana dan Anak Pidana yang telah melakukan perbuatan yang membantu kegiatan pembinaan di Lembaga Pemasyarakatsebagai pemuka.

Dan dari hasil wawancara dengan beberapa narapidana narkotika yang dengan vonis hukuman bermacam-macam, para narapidana narkotika juga ada beberapa yang masih belum mendapatkan remisi dikarenakan masih belum menjalani masa pidana minimal 6 (enam) bulan, ${ }^{14}$ beberapa juga mengatakan bahwa telah mendapatkan remisi total 8 (delapan) bulan selama beberapa tahun menjalani masa pidananya, ${ }^{15}$ walaupun dengan adanya remisi yang diberikan kepada pelaku tindak pidana narkotika mereka sudah merasa jera, walaupun ada pengurangan hukuman namun hukuman yang telah diberikan oleh hakim sudah membuat jera dan tidak akan mengulangi kesalahannya.

Para narapidana narkotika yang sudah berkelakuan baik dan juga dianggap mampu dalam hal informatika atau lainya mereka diberi pekerjaan sebagai pembantu petugas atau staf-staf di LAPAS mereka di sebut dengan taming, bahkan ada juga narapidana narkotika yang bertugas dibagian register mereka diberikan kebebasan untuk berkomunikasi dengan keluarga, namun ketika mereka kembali kedalam kamar tahanan mereka kembali menjadi narapidana sebagaimana umumnya.

\footnotetext{
${ }^{14}$ Juansa Pradana, Wawancara, Lembaga Pemasyarakatan Sidoarjo, 28 Desember 2015.

${ }^{15}$ Fandi Dwinata, Wawancara, Lembaga Pemasyarakatan Sidoarjo, 28 Desember 2015.
} 
Sebagaimana yang telah diatur dalam Peraturan Pemerintah Republik Indonesia nomor 99 Tahun 2012 tentang perubahan atas Peraturan Pemerintah Republik Indonesia nomor 28 Tahun 2006 tentang Syarat dan Tata Cara Pelaksanaan Hak Warga Binaan Pemasyarakatan perubahan pasal $34 \mathrm{~A}$ bahwa pemberian remisi bagi narapidana yang dipidana karena melakukan tindak pidana terorisme, narkotika dan prekursor narkotika, psikotropika, korupsi, kejahatan terhadap keamanan negara, kejahatan hak asasi manusia yang berat, serta kejahatan transnasional terorganisasi lainnya, selain harus memenuhi persyaratan sebagaimana dimaksud dalam Pasal 34 juga harus memenuhi persyaratan dalam hal ini bagi pelaku tindak pidana narkotika harus bersedia bekerjasama dengan penegak hukum untuk membantu membongkar perkara tindak pidana yang dilakukannya, dan kesediaan untuk bekerjasama sebagaimana dimaksud diatas harus dinyatakan secara tertulis dan ditetapkan oleh instansi penegak hukum sesuai dengan ketentuan peraturan perundang-undangan. Dalam hal ini di lapas Sidoarjo kesediaan tersebut dinyatakan secara tertulis dan ditandatangani diatas materai oleh yang bersangkutan (pelaku tindak pidana narkotika).

Dalam hal pemberian remisi kepada narapidana Menteri Hukum dan HAM dapat mendelegasikan pelaksanaannya kepada kepala kantor wilayah. Penetapan pemberian remisi dilaksanakan dengan keputusan kepala kantor wilayah atas nama menteri, setelah mengeluarkan penetapan kepala kantor wilayah wajib menyampaikan laporan tentang penetapan pengurangan masa pidana tersebut kepada menteri Departemen Hukum Dan Ham Cq.Dirjen pemasyarakatan. ${ }^{16}$

Remisi memang diberikan kepada semua narapidana atau anak pidana narkotika namun ada pengecualian seperti halnya yang tercantum dalam Keputusan Presiden nomor 174 tahun 1999 bahwa Remisi tidak diberikan kepadanarapidana atau anak pidana yang:

1. Dipidana kurang dari 6 (bulan).

2. Dikenakan hukuman disiplin dan didaftar pada buku pelanggaran tata tertib lembaga pemasyarakatan dalam kurun waktu yang diperhitungkan pada pemberian Remisi.

3. Sedang menjalani cuti menjelang bebas.

\footnotetext{
${ }^{16}$ Kepmen Hukum dan Perundang-Undangan No.M.09.HN.02.01 Tahun 1999 tentang Pelaksanaan Keputusan Presiden No.174 Tahun 1999.
} 
4. Dijatuhi pidana kurungan sebagai pengganti pidana denda. ${ }^{17}$

Oleh karena itu dari hasil wawancara ada beberapa narapidana yang belum mendapatkan remisi dikarenakan belum menjalani masa pidana enam bulan. Dan sebuah pengurangan hukuman yang diberikan oleh Kementerian Hukum dan Hak Asasi Manusia bukan mengurangi efek jera kepada pelaku tindak pidana narkotika karena remisi merupakan hak dari narpidana atau anak pidana bila sudah memenuhi syarat, selain itu narapidana narkotika juga mengaku bahwa dirinya sudah jera dan menyesal telah melakukan kesalahan yang telah dilakukannya. Dan setiap tahunnya remisi diberikan, dan dihitung.

\section{Analisis Pemberian Remisi kepada Pelaku Tindak Pidana Narkotika di Lembaga Pemasyarakatan Sidoarjo}

Pada dasarnya penjatuhan hukuman (pidana) buka hanya sematamata memberikan efek jera saja, namun penjatuhan hukuman juga memberikan bimbingan dan pembinaan. Dalam hal pelaksanaan hukuman bagi terpidana dilaksanakan di Lembaga Pemasyarakatan (Lapas), dimana di dalam lapas narapidana diberikan pembelajaran, bimbingan serta pembinaan, dengan tujuan agar narapidana tidak mengulangi kesalahannya dan juga sadar dengan perbuatannya bahwa yang pernah dia lakukan itu adalah kesalahan dan tidak akan mengulangi lagi, serta kembali ke masyarakat dengan menjalankan fungsinya seperti sebelumnya.

Departemen Hukum dan Hak Asasi Manusia Republik Indonesia adalah: Departemen Pemerintah yang mengurusi pelayanan publik kepada masyarakat. Dimana Departemen Hukum Dan HAM membawahi Direktorat Jenderal Pemasyarakatan yang membawahi LAPAS. LAPAS merupakan bagian Pemerintah yang menjalankan pelayanan publik. Sejarah kepenjaraan yang berkembang dari zaman penjara sampai pada sistem pemasyarakatan. Sistem pemasyarakatan merupakan bentuk penegakan hak asasi manusia yang mengutamakan pelayanan hukum dan pembinaan narapidana. Pelayanan hukum dan pembinaan narapidana ini merupakan suatu pelayanan publik Pemerintah yang diberikan kepada masyarakat. ${ }^{18}$

\footnotetext{
${ }^{17}$ Kepres No.174 Tahun 1999 tentang Remisi.

${ }^{18}$ Muhammad Thohir," Tinjauan Hukum Pidana Islam Terhadap Pemberian Remisi Kepada Pelaku Tindak Pidana Pembunuhan..., 80.
} 
Di dalam lembaga pemasyarakatan, narapidana sebagai warga binaan pemasyarakatan juga mempunyai hak, sebagaimana yang telah diatur dalam dalam Pasal 14 ayat (1) Undang- undang No.12 tahun 1995 yaitu:

a. Melakukan ibadah sesuai dengan agama atau kepercayaannya.

b. Mendapatkan perawatan baik perawatan jasmani maupun perawatan rohani.

c. Mendapatkan pendidikan dan pengajaran.

d. Mendapatkan pelayanan kesehatan dan makanan yang layak.

e. Menyampaikan keluhan.

f. Mendapatkan bahan bacaan dan mengikuti siaran media masa lainnya yang tidak dilarang.

g. Mendapatkan upah dan premi atas pekerjaan yang dilakukan.

h. Menerima kunjungan keluarga, penasehat hukum, atau orang tertentu yang lainnya.

i. Mendapatkan pengurangan masa pidana ( remisi).

j. Mendapatkan kesempatan berasimilasi termasuk cuti mengunjungi keluarga.

k. Mendapatkan pembebasan bersyarat

1. Mendapatkan cuti menjelang bebas dan;

m. Mendapatkan hak- hak lain sesuai dengan peraturan perundangundangan yang berlaku. ${ }^{19}$

Sebagaimana yang telah dijelaskan di atas bahwa remisi juga termasuk hak bagi setiap warga binaan pemasyarakatan, oleh karena itu pada umumnya semua narapidana atau anak pidana berhak mendapatkan remisi, yang khususnya adalah narapidana narkotika.

Remisi merupakan pengurangan masa pidana yang diberiakan oleh Kementerian Hukum dan Hak Asasi Manusia kepada narapidana atau anak pidana yang telah memenuhi syarat, sebagaimana yang telah dijelaskan pada bab sebelumnya bahwa syarat yang harus dipenuhi untuk memperoleh remisi yang dijelaskan dalam Keputusan Presiden nomor 174 tahun 1999 syarat pemberian remisi yaitu, berkelakuan baik dan telah menjalani masa pidananya selama 6 bulan.

Dalam hal pemberian remisi kepada pelaku tindak pidana narkotika juga terdapat persyaratan yang diatur dalam Peraturan Pemerintah nomor 99 tahun 2012 tentang Perubahan Atas Peraturan Pemerintah Republik

${ }^{19}$ Undang- undang No.12 Tahun 1995. 
Indonesia nomor 28 tahun 2006 Tentang Syarat dan Tata Cara Pelaksanaan Hak Warga Binaan Pemasyarakatan bahwa pelaku tindak pidana narkotika harus bersedia membantu penegak hukum untuk membongkar kasusnya. Menurut penulis dalam hal pemberian syarat yang seperti demikian pelaku tindak pidana narkotika akan lebih berfikir dua kali untuk tidak bersedia membantu penegak hukum dalam membongkar kasusnya, seperti yang telah diketahui bahwa kasus narkotika tidak hanya dilakukan oleh satu atau dua orang saja, karena narkotika di negara ini sudah menyebar luas bahkan narkotika juga sudah dikenal dikalangan anak sekolah atau siswa. Di lembaga pemasyarakatan Sidoarjo kesediaan membantu penegak hukum dalam membongkar kasusnya tersebut dinyatakan dengan tertulis dan ditandatangani diatas materai.

Dengan adanya syarat seperti itu narapidana tidak akan meremehkan masa tahanan yang telah diputus oleh hakim, karena syarat tersebut merupakan kewajiban yang harus dipenuhi oleh setiap narapidana narkotika, mengingat begitu bebasnya narkotika di masyarakat dan dampaknya yang sangat berbahaya.

Seperti halnya ada beberapa jenis remisi, di lembaga pemasyarakatan Sidoarjo remisi juga diberikan dengan berbagai jenis, yaitu:

a. Remisi umum yang diberikan kepada narapidana pada hari kemerdekaan negara Republik Indonesia pada tanggal 17 Agustus,

b. Remisi khusus yang diberikan kepada narapidana atau anak pidana pada hari raya keagamaan

c. Remisi tambahan yang diberikan kepada narapidana yang menjadi pemuka di lembaga pemasyarakatan untuk membantu melakukan atau melancarkan peraturan yang ada di lembaga pemasyarakatan

d. Remisi dasawarsa yang diberikan kepada narapidana atau anak pidana dalam sepuluh tahun sekali.

Jenis-jenis remisi yang diberikan di lembaga pemasyarakatan Sidoarjo memang sangat bervariasi namun dengan bervariasi tersebut narapidana narkotika pastilah mendapatkan haknya setelah menjalani masa pidana selama enam bulan dan telah berkelakuan baik selama menjalani masa pidananya, dengan menerima haknya yaitu remisi para narapidana narkotika merasa hal tersebut tidak mengurangi sedikitpun rasa jera atas hukuman yang telah diputus oleh hakim di pengadilan. 
Sebagaimana jenis remisi tersebut besar remisi yang diberikan kepada narapidana narkotika di lembaga pemasyarakatan Sidoarjo yaitu:

\begin{tabular}{|c|c|c|}
\hline Jenis Remisi & Banyaknya Remisi & $\begin{array}{c}\text { Syarat-syarat } \\
\text { (Lama menjalani } \\
\text { hukuman) }\end{array}$ \\
\hline Remisi Umum & $\begin{array}{l}\text { bulan } \\
2 \text { bulan } \\
3 \text { bulan } \\
4 \text { bulan } \\
5 \text { bulan } \\
6 \text { bulan } \\
\end{array}$ & $\begin{array}{l}6 \text { sampai12 bulan } \\
12 \text { bulan / lebih } \\
2 \text { tahun } \\
3 \text { tahun } \\
4 \text { atau } 5 \text { tahun } \\
6 \text { tahun dan seterusnya }\end{array}$ \\
\hline Remisi Khusus & $\begin{array}{l}15 \text { hari } \\
1 \text { bulan } \\
1 \text { bulan } 15 \text { hari } \\
2 \text { bulan }\end{array}$ & $\begin{array}{l}6 \text { sampai } 12 \text { bulan } \\
12 \text { bulan atau lebih } \\
4 \text { sampai dengan } 5 \\
\text { tahun } \\
6 \text { tahun dan seterusnya }\end{array}$ \\
\hline $\begin{array}{l}\text { Remisi } \\
\text { Tambahan }\end{array}$ & $\begin{array}{ll}1 / 2 \quad \text { dari } & \text { remisi } \\
\text { umum } & \\
1 / 3 \text { dari } & \text { remisi } \\
\text { umum } & \end{array}$ & $\begin{array}{l}\text { - Berbuat jasa kepada } \\
\text { negara } \\
\text { - Berbuat yang } \\
\text { bermanfaat bagi negara } \\
\text { dan kemanusiaan. } \\
\text { - Membantu kegiataan } \\
\text { pembinaan di lembaga } \\
\text { pemasyarakatan sebagai } \\
\text { pemuka. }\end{array}$ \\
\hline $\begin{array}{l}\text { Remisi } \\
\text { Dasawarsa } \\
\text { (diberikan } \\
\text { setiap } 10 \text { tahun } \\
\text { sekali) }\end{array}$ & $\begin{array}{l}1 / 12 \text { dari hukuman } \\
3 \text { bulan }\end{array}$ & $\begin{array}{l}\text {-Berkelakuan baik } \\
\text {-Telah menjalani masa } \\
\text { pidana } 6 \text { bulan }\end{array}$ \\
\hline
\end{tabular}

Setiap narapidana narkotika yang berada di lembaga pemasyarakatan sidoarjo berhak mendapatkan pengurangan hukuman, hukuman yang dimaksud disini adalah penjara, dimana penjara merupakan tempat manjalani masa pidananya. Mengenai pidana penjara dijatuhkan untuk seumur hidup atau untuk waktu tertentu. Waktu 
tertentu dijatuhkan paling lama lima belas tahun penjara berturut-turut atau paling singkat satu hari, kecuali ditentukan minimum khusus. ${ }^{20}$

Remisi diberikan karena merupakan salah satu sarana hukum yang penting dalam rangka mewujudkan tujuan sistem pemasyarakatan, selain itu remisi diberikan karena negara Indonesia menjamin kemerdekaan tiaptiap penduduk untuk memeluk agamanya masing-masing, termasuk narapidana narkotika, sehingga dengan adanya hal tersebut tidak menimbulkan diskriminasi sosial, dan narapidana juga mendapatkan haknya yang memang harus diporoleh.

Memang banyak masyarakat yang beranggapan bahwa remisi diberikan kepada pelaku tindak pidana narkotika itu tidak memberikan efek jera, karena tidak sepadan dengan apa yang telah dilakukannya selama berada di masyarakat, namun menurut hasil wawancara dengan beberapa narapidana bahwa semua mengatakan bahwa mereka telah jera dan tidak akan mengulangi semua perbuatannya, walaupun dengan diberikannya remisi kepada pelaku tindak pidana narkotika tidak sama sekali mengulangi efek jera dengan hukuman yang telah dijatuhkan oleh hakim kepada mereka. Karena dengan menjalani masa pidananya mereka sudah sangat merasa jera dengan dirampasnya kebebasan mereka untuk bersosialisasi di masyarakat.

Remisi yang diberikan kepada pelaku tindak dipidana narkotika bukan semata-mata diberikan, namun juga harus melengkapi persyaratan yang telah tercantum dalam Keppres RI No 174 tahun 1999, yang pada umumnya syarat mendapatkan remisi tersebut adalah harus menjalani masa pidana 6 bulan. Selama menjalani masa 6 bulan tersebut narapidana narkotika harus berkelakuan baik. Dalam hal berkelakuan baik semua warga binaan pemasyarakatan diawasi oleh petugas dan juga sesama temannya, dengan syarat yang demikian, maka bagi pelaku tindak pidana narkotika bukanlah hal yang mudah seperti yang difikirkan oleh masyarakat.

Jika melihat undang-undang no 35 tahun 2009 tentang narkotika, bahwa hukuman bagi pelaku tindak pidana narkotika yang termuat dalam pasal 111 ayat (1) yang berbunyi Setiap orang yang tanpa hak atau melawan hukum menanam, memelihara, memiliki, menyimpan, menguasai, atau menyediakan narkotika golongan I dalam bentuk tanaman, dipidana dengan pidana penjara paling singkat 4 (empat) tahun

${ }^{20}$ Bambang Waluyo, Pidana dan Pemidanaan, (Jakarta: Sinar Grafika, 2000), 16. 
dan paling lama 12 (dua belas) tahun dan pidana denda paling sedikit Rp800.000.000,00 (delapan ratus juta rupiah) dan paling banyak Rp8.000.000.000,00 (delapan miliar rupiah). Pasal 112 ayat (1) Setiap orang yang tanpa hak atau melawan hukum memiliki, menyimpan, menguasai, atau menyediakan narkotika golongan I bukan tanaman, dipidana dengan pidana penjara paling singkat 4 (empat) tahun dan paling lama 12 (dua belas) tahun dan pidana denda paling sedikit Rp800.000.000,00 (delapan ratus juta rupiah) dan paling banyak Rp8.000.000.000,00 (delapan miliar rupiah). Pasal 113 ayat (1) Setiap orang yang tanpa hak atau melawan hukum memproduksi, mengimpor, mengekspor, atau menyalurkan Narkotika Golongan I, dipidana dengan pidana penjara paling singkat 5 (lima) tahun dan paling lama 15 (lima belas) tahun dan pidana denda paling sedikit Rp1.000.000.000,00 (satu miliar rupiah) dan paling banyak Rp10.000.000.000,00 (sepuluh miliar rupiah). Pasal 114 ayat (1) Setiap orang yang tanpa hak atau melawan hukum menawarkan untuk dijual, menjual, membeli, menerima, menjadi perantara dalam jual beli, menukar, atau menyerahkan Narkotika Golongan I, dipidana dengan pidana penjara seumur hidup atau pidana penjara paling singkat 5 (lima) tahun dan paling lama 20 (dua puluh) tahun dan pidana denda paling sedikit Rp1.000.000.000,00 (satu miliar rupiah) dan paling banyak Rp10.000.000.000,00 (sepuluh miliar rupiah).

Dari penjelasan pasal-pasal yang memuat tentang hukuman bagi pelaku tindak pidana narkotika tidak ringan karena dengan hukuman sedemikian rupa itu sangat memberatkan pelakunya, dan dengan diberikannya remisi setidaknya mengurangi hukuman namun dengan adanya remisi tersebut tidak sama sekali mengurangi efek jera hukuman yang telah dijatuhkan kepadanya, dengan syarat yang telah ditentukan dalam peraturan-peraturang yang ada.

Remisi yang diberikan kepada pelaku tindak pidana narkotika seperti halnya telah diterangkan di atas, bahwa remisi yang diberikan kepada pelaku tindak pidana narkotika di lembaga pemasyarakatan Sidoarjo yaitu remisi umum seperti halnya yang telah tercantum dalam Keputusan Presiden nomor 174 tahun 1999, di mana remisi umum ini diberikan kepada semua pelaku tindak pidana narkotika yang telah memenuhi syarat, dan diberikan pada hari kemerdekaan Negara Republik Indonesia, yang mana remisi diumumkan pada hari upacara kemerdekaan di pendopo Kabupaten Sidoarjo. 
Selanjutnya, remisi yang diberikan kepada pelaku tindak pidana narkotika adalah remisi khusus, yang juga telah diatur dalam Keputusan Presiden nomor 174 tahun 1999, remisi khusus diberikan pada saat hari keagamaan para pelaku tindak pidana narkotika, namun dalam hal mengumumkan pemberian remisi khusus di lembaga pemasyarakatan sidoarjo, kebanyakan narapidana narkotika tidak mengetahui bahwa mereka telah diberi haknya dengan remisi, ada juga yang telah mengetahui bahwa telah mendapatkan remisi namun tidak mengetahui berapa besar remisi yang telah diterimanya.

Remisi yang diberikan selanjutnya adalah remisi tambahan, remisi tambahan di lembaga pemasyarakatan Sidoarjo jarang diberikan karena mengingat persyaratan untuk remisi tambahan tersebut sangat sulit di penuhi oleh pelaku tindak pidana narkotika tersebut.

Jenis remisi lain yang diberikan kepada pelaku tindak pidana narkotika di lembaga pemasyarakatan Sidoarjo yaitu remisi dasawarsa, dimana remisi dasawarsa diberikan setiap 10 tahun sekali dan besarnya remisi dasawarsa yaitu $1 / 12$ dari hukuman yang telah divonis hakim atau setinggi-tinnginya 3 bulan, demikian yang telah dijelaskan dalam Keputusan Presiden nomor 120 tahun 1955.

Remisi yang diberikan kepada pelaku tindak pidana narkotika memang beragam, namun sangat disayangkan jika para pelaku tindak pidana narkotika tidak dapat mengetahui bahwa mereka telah mendapatkan haknya berupa keringanan hukuman atau remisi, sehingga menurut penulis seharusnya segala bentuk remisi yang diberikan kepada pelaku tindak pidana narkotika di lembaga pemasyarakatan sidoarjo harus di umumkan karena dengan adanya pengumuman tersebut para narapidana narkotika dapat mengetahui bahwa dirinya telah diberikan haknya berupa peringanan hukuman atau yang disebut dengan remisi, dan jika para narapidana mengetahui hal tersebut pastilah mempunyai motivasi untuk menjadi lebih baik.

\section{Tinjauan Hukum Pidana Islam terhadap Pemberian Remisi kepada Pelaku Tindak Pidana Narkotika di Lembaga Pemasyarakatan Sidoarjo}

Narkotika termasuk jenis obat-obatan dan lain sebagainya yang dapat menyebabkan orang menjadi mabuk atau lupa ingatan. Dalam hukum Islam disebut sebagai khamr. Dalam hukum pidana Islam, narkotika dianalogikan seperti khamr yang hukuman bagi pengguna 
maupun pengedarnya adalah hâd, baik narkotika itu berupa ganja, sabusabu atau yang lainnya.

Di Lembaga Pemasyarakatan Sidoarjo, pengguna maupun pengedar dikenakan sanksi yang telah tercantum di Undang-undang Nomor 35 Tahun 2009 yang hukumannya juga beragam setiap tindak pidana yang dilakukan. Demikian pula dalam hukum pidana Islam hukuman bagi pengguna narkotika dan penggedar narkotika juga mendapat hukuman yang setimpal dengan perlakuannya.

Ulama' banyak yang menganalogikan narkoba dengan khamr, karena illat yang sama yaitu sama-sama memabukkan. Namun ada juga yang berpendapat bahwa narkotika lebih berbahaya dibandingkan dengan khamr karena narkotika lebih banyak bahayanya bahkan dapat merusak jasmani dan rohani bagi penggunannya. Sedangkan khamr hanya dapat memabukkan dan setelah itu hilang efeknya. Narkoba membuat dampak yang lebih banyak dibanding khamr, yaitu kecanduan. Namun demikian, tidak menutup kemungkinan juga pengguna khamr akan kecanduan.

Para ulama' berbeda pendapat mengenai sanksi bagi pelaku penyalahgunaan narkotika. Jika dilihat dari hukum pidana Islam, ada yang berpendapat sanksinya adalah had karena narkotika dianalogikan dengan khamr, dimana hukuman bagi peminum khamr adalah had. Namun ada juga yang berpendapat hukumannya adalah ta'zîr dengan alasan bahwa narkoba tidak ada pada masa Rasulullah; narkoba lebih berbahaya dibandingkan dengan khamr, dan narkoba tidak diminum seperti halnya khamr.

Al-Qur'an dan sunnah tidak menjelaskan tentang sanksi bagi produsen dan pengedar narkoba. Oleh karena itu, sanksi hukum bagi produsen dan pengedar narkoba adalah ta'zîr. Hukuman ta'zîr bisa berat atau ringan tergantung kepada proses pengadilan (otoritas hakim). Bentuk dan sanksinya pun bisa beragam. Fatwa Majelis Ulama Indonesia (MUI) mengatakan bahwa sanksi bagi pelaku penyalahgunaan narkotika adalah ta'zîr. Karena penyalahgunaan narkotika mengakibatkan kerugian jiwa dan harta benda, maka perlu dilakukan tindakan-tindakan berikut:

a. Menjatuhkan hukuman yang berat kepada penjual, pengedar, dan penyelundupan bahan-bahan narkoba. Jika perlu hukuman mati.

b. Menjatuhkan hukuman berat terhadap aparat negara yang melindungi produsen atau pengedar narkoba. 
c. Membuat undang-undang mengenai penggunaan dan penyalahgunaan narkoba. ${ }^{21}$

Jadi menurut penjelasan di atas bahwa narkotika bisa dianalogikan dengan khamr dan pasti hukumannya adalah hudûd, dimana jarîmah hudûd ini adalah jarîmah yang bentuknya telah ditentukan oleh syara ${ }^{22}$. Selain ditentukan bentuknya, juga ditentukan hukuman yang jelas baik ditentukan dalam al-Qur'an maupun sunnah. Lebih dari itu, jarîmah ini termasuk dalam jarîmah yang menjadi hak tuhan. Jarîmah-jarîmah yang telah menjadi hak tuhan, pada prisipnya adalah jarîmah yang menyangkut masyarakat banyak, yaitu untuk memelihara kepentingan, ketenteraman, dan keamanan masyarakat. Oleh karena itu, hak Allah identik dengan hak masyarakat, maka pada jarîmah ini tidak dikenal dengan pemaafan atas perbuatan jarîmah, baik oleh perseorangan yang menjadi korban jarîmah (mujnâ alaih) maupun oleh negara.

Pendapat lain ada yang mengatakan bahwa narkotika termasuk jarîmah ta'zîr dikarenakan berbagai alasan yang telah disebutkan diatas, ta'zîr menurut arti katanya adalah at-ta'dîb yang artinya memberi pengajaran. Dalam fiqh jinayah, ta'zîr merupakan bentuk jarîmah yang bentuk atau macam jarîmah serta hukuman sanksi jarîmah ini ditentukan penguasa. Jadi, jarîmah ini sangat berbeda dengan jarîmah hudûd dan qishâsh/diyat yang macam jarîmah dan bentuk hukumannya telah ditentukan oleh syara. Tidak ditentukan macam dan hukuman pada jarîmah ta'zîr sebab jarîmah ta'zîr ini berkaitan dengan perkembangan masyarakat serta kemaslahatannya, seperti yang kita ketahui bahwa kemaslahatan selalu berubah berkembang dari satu waktu ke lain waktu dan dari satu tempat ketempat lain. Oleh karena itu, sesuatu dapat dianggap kemaslahatan pada suatu masa, bisa jadi tidak demikian pada masa yang lainnya.

Jarîmah ta'zîr sering disebut dengan jarîmah kemaslahatan umum. Dan mengenai hukuman, syara hanya menyebutkan bentuk-bentuk hukumannya, dari yang seberat-beratnya hingga seringan-ringannya. Tanpa mengharuskan hukuman tertentu untuk jarîmah tertentu pula, seperti pada jarîmah hudûd dan qishash/diyat. Dalam menangani jarîmah ini, hakim diberikan keleluasaan. Dia bebas berijtihad untuk menentukan

\footnotetext{
${ }^{21}$ Nurul Irfan dan Masyarofah, Fiqh Jinayah .., 178.

${ }^{22}$ Rahmat Hakim, Hukum Pidana Islam (fiqih Jinayah), ( Bandung: Pustaka Setia, 2000), 26.
} 
apa yang hendak dijatuhkan kepada pelaku jarîmah, sesuai dengan macam jarîmahnya dan keadaan pelaku jarîmah.

Narkotika memang mempunyai persamaan illat dengan khamr yaitu sama-sama membuat orang menjadi hilang ingatan, namun dalam hal hukuman bagi pelaku tindak pidana narkotika ini, menurut penulis dapat digolongkan dengan jarîmah ta'zîr karena hukuman yang diberikan kepada pelaku tindak pidana narkoti di lembaga pemasyarakatan Sidoarjo ini merupakan hukuman yang dijatuhkan oleh hakim, besar kecilnya hukuman yang dijatuhkan juga tercantum dalam beberapa peraturan yang telah mengaturnya.

Dikatakan ta'zîr disini, karena memang narkotika tidak berada disebutkan di dalam syara namun hanya hasil ijtihad para ulama yang menyamakan narkotika dengan khamr namun perlu di ingat bahwa narkotika selain mempunyai kesamaan illat dengan khamr namun narkotika lebih banyak mempunyai madharatnya, sehingga dalam menjatuhkan suatu hukuman otoritas hakim sangat diperlukan.

Istilah remisi dalam hukum pidana Islam memang tidak dijumpai seperti halnya dalam bahasa Indonesia, kata remisi merupakan kata serapan dari bahasa Inggris yaitu remission, yang berarti ${ }^{23}$ pengampunan, pemaafan, pengurangan. Yang dalam bahasa Indonesia remisi diartikan pengampunan atau pengurangan hukuman.

Dalam istilah Arab memang tidak dijumpai pengertian yang pasti mengenai kata remisi, tetapi ada beberapa istilah yang hampir sepadan dengan makna remisi itu sendiri, yaitu al-Afw (maaf, ampunan), ghafar (ampunan), rukhshah (keringanan), syafa'at (pertolongan), takhfif (pengurangan). Selain itu menurut Sayid Sabiq memaafkan disebut juga dengan al-Qawdu' "menggiring" atau memaafkan yang ada halnya dengan diyat atau rekonsiliasi tanpa diyat walau melebihinya. ${ }^{24}$

Dalam Islam dikenal dengan adanya syafáat, syafa'at dibagi menjadi dua yaitu syafa'at qiyâdah (kepemimpinan) dan syafa'at maghfirah (ampunan). ${ }^{25}$ Secara garis besar syafa'at yang datang dari rahmat Allah, sumber kebaikan dan rahmat disebut sebagai ampunan (maghfirah) dan yang datang melalui perantara-perantara rahmat disebut

\footnotetext{
${ }^{23}$ Sandi Putra, Kamus lengkap, (Surabaya: Gereisinda Press, tt), 318.

${ }^{24}$ M. Fahmi Al-Amruzi, "Analisis Hukum Pemberian Remisi Terhadap Pelaku Tindak Pidana"..., 2.

${ }_{25}^{25}$ Muhammad Thohir, "Tinjauan Hukum Pidana Islam Terhadap Pemberian Remisi Kepada Pelaku Tindak Pidana Pembunuhan (Studi Analisis Keppres Nomor 174 Tahun 1999)", (Fakultas Syariah Institut Agama Islam Negeri Walisongo Semarang, 2012), 90.
} 
dengan syafa'at. Melihat penjelasan diatas maka menurut penulis remisi dapat disebut juga dengan syafa'at qiyâdah, maksudnya adalah syafa'at yang dimiliki oleh seorang pemimpin yang diberikan kepada rakyatnya, pada zaman dahulu Rasulullah saw adalah seorang syafi' (perantara syafa'at) bagi amir al mu'minin dan Fathimah al-Zahra dan keduanya menjadi syafi' bagi Hasan dan Husain. Setiap imam menjadi syafi' bagi imam yang lain, murid-muridnya dan semua pengikutnya. Hierarki ini tetap terjaga sehingga semua yang dimiliki oleh para imam ma'shum mereka peroleh melalui perantaraan Rasulullah yang mulia.

Istilah yang terkait dengan remisi dalam hukum pidana yang sering digunakan dan memiliki makna hampir menyerupai istilah remisi adalah takhfif al-uqûbah (peringanan hukuman). Dalam Ensiklopedi Hukum Pidana Islam, peringanan atau pengampunan hukuman merupakan salah satu sebab pengurungan (pembatalan) hukuman, baik diberikan oleh korban, walinya, maupun penguasa. ${ }^{26}$

Dari beberapa penjelasan diatas diterangkan bahwa hukuman bagi pelaku tindak pidana narkotika dalam hukum pidana Islam ada yang mengatakan termasuk jarîmah hudûd dan ada pendapat yang mengatakan masuk jarîmah ta'zîr. Memang bila dilihat dari illat nya narkotika samasama memabukkan dan membahayakan jiwa dengan khamr, oleh karena itu narkotika bisa dikatakan masuk jarîmah hudûd, namun tidak menutup kemungkinan juga bahwa narkotika juga masuk dalam jarîmah ta'zîr.

Dalam refrensi lainnya mengatakan bahwa narkotika bila disamakan dengan khamr al-Qur'an tidak menegaskan hukuman apa bagi peminum khamr. Sanksi terhadap delik ini disandarkan pada hadis nabi yakni melalui sunnah fi'liyah-nya, bahwa hukuman terhadap jarîmah ini adalah 40 kali dera. Abu Bakar mengikuti jejak ini. Tetapi, Umar Ibnu Khathab menjatuhkan 80 kali dera kali didasarkan pada metode analogi, yakni dengan mengambil ketentuan hukum yang ada dalam surah an-Nur ayat 4 yang berbunyi:

Dan orang-orang yang menuduh perempuan-perempuan yang baik (berzina) dan mereka tidak mendatangkan empat orang saksi, maka deralah mereka delapan puluh kali, dan janganlah kamu terima kesaksian mereka untuk selama-lamanya. Mereka itulah orang-orang yang fasik. ${ }^{27}$

\footnotetext{
${ }^{26}$ Abdul Qadir Awdah, Ensiklopedia Hukum Pidana Islam, (Ahsin Sakho Muhammad dkk), Jilid III. (Jakarta: PT Kharisma Ilmu, 2008), 168.

${ }^{27}$ Departemen Agama RI, Al-Qur'an dan Terjemahnya..., 488.
} 
Dari penjelasan ayat diatas, dianalogikan bahwa orang yang menuduh zina dicambuk 80 kali. Orang mabuk biasanya suka mengigau, kalau mengigau suka membuat kebohongan, orang bohong sama dengan membuat fitnah. Fitnah dikenakan hukuman 80 kali cambukan, maka peminum khamr dihukum 80 kali deraan. Menurut Imam Abu Hanifah dan Imam Malik, sanksi peminum khamr adalah 80 kali dera, sedangkan menurut Imam Syafii adalah $40 \mathrm{kali}$ dera, tetapi Imam boleh menambahkan menjadi 80 kali dera. Jadi 40 kali adalah hukuman had, sedangkan sisanya adalah hukuman ta’zîr.

Jarîmah ta'zîr juga ada yang berkaitan dengan hak hamba dan juga hak Allah, pembagian tersebut memang sangat penting sehingga pembaca dapat mengetahui bahwa jarîmah ta'zîr bukan hanya sekedar jarîmah yang hukumannya hanya menyangkut kepada manusia saja, berikut penjelasannya: ${ }^{28}$

a. Untuk ta'zîr yang berkaitan dengan hamba disamping harus ada gugatan, Ulul Amri tidak dapat memaafkan, sedangkan ta'zîr yang berkaitan dengan hak Allah atau jarîmah tidak harus ada gugatan dan ada kemungkinan bila Ulil Amri untuk memberi pemaafan bila hal itu membawa kemaslahatan, jadi dalam kasus ta'zîr yang berkaitan dengan hak Allah ada kemungkinan Ulul Amri mendeponir perkara bila cara itu dipandang membawa kemaslahatan.

b. Dalam ta'zîr yang berkaitan dengan hak hamba tidak dapat diberlakukan teori tadâkhul. Jadi sanksinya dijumlahkan sesuai dengan banyaknya kejahatan.

c. Ketika tindak pidana ta'zîr yang berkaitan dengan hak Allah berlangsung semua wajib mencegahnya, dalam hal ini merupakan penerapan nahi munkar. Adapun setelah terjadinya kejahatan, maka hak menjatuhi hukuman berada di tangan Ulil Amri.

d. Ta'zîr yang berkaitan dengan hak perorangan dapat diwariskan kepada asli waris korban bila tidak sempat mengajukan gugatan sedangkan ia telah berniat untuk itu. Adapun ta'zîr yang berkaitan dengan hak Allah tidak dapat diwariskan.

Dengan berbagai pendapat, penulis setuju dengan pendapat Imam Syafi'i yang mengatakan bahwa hukuman bagi peminum khamr adalah

\footnotetext{
${ }^{28}$ A. Djazuli, Fiqh Jinayah (Upaya Menanggulangi Kejahatan dalam Islam), (Jakarta: PT Raja Grafindo Persada, 2000), 167.
} 
40 kali cambukan termasuk hudûd dan hakim boleh menambah dengan 40 kali cambukan yang disebut dengan ta'zîr.

Dari pendapat yang demikian itu dapat diketahui juga pada bab sebelumnya yang telah dijelaskan bahwa remisi atau pengampunan jarîmah hudûd itu tidak bisa diberikan dikarenakan jarîmah hudûd itu jarîmah yang berhubungan langsung dengan Allah, berbeda dengan jarîmah ta'zîr yang bisa diberikan remisi atau pengampunan atau dengan kata lain peringanan hukuman, dalam ensiklopedia hukum pidana Islam mengatakan bahwa penguasa boleh memberikan ampunan atau mengampuni suatu tindak pidana ta'zîr dan hukumannya, baik sebagiannya maupun keseluruhannya, sebagian ulama juga berpendapat bahwa penguasa memiliki hak untuk memberikan pengampunan atas seluruh tindak pidana yang diancam dengan hukuman ta'zîr dan juga hak mengampuni hukumannya jika di dalamnya terdapat kemaslahatan umum.

Jadi penulis mempunyai pendapat bahwa kejahatan narkotika yang dilakukan oleh narapidana narkotika di lembaga pemasyarakatan Sidoarjo termasuk dalam jarîmah ta'zîr, karena narkotika efeknya memang lebih berbahaya dari pada khamr dan juga narkotika lebih banyak madharatnya, narkotika bisa saja merusak masa depan seorang anak, narkotika juga bisa membuat kejahatn-kejahatan lainnya, oleh karena itu sanksi hukum bagi pelaku tindak pidana narkotika termasuk ta'zîr. Hukuman ta'zîr bisa berat atau ringan tergantung kepada proses pengadilan (otoritas hakim), dan bentuk sanksinya juga beragam.

Pemberian remisi di lembaga pemasyarakatan Sidoarjo merupakan hak bagi setiap narapidana narkotika yang memang harus diberikan bila narapidana narkotika telah memenuhi syarat, karena suatu hak akan diberikan bila syarat atau kewajiban telah dipenuhi, masyarakat berpandangan bahwa remisi di lembaga pemasyarakatan Sidoarjo sangatlah mudah, namun menurut hasil penelitian remisi diberikan bukan dengan secara cuma-cuma atau semudah pandangan masyarakat, karena remisi diberikan kepada narapidana narkotika dengan syarat harus berkelakuan baik selama menjalani masa pidana atau dalam hukum pidana Islam, narapidana narkotika telah menyesal dan bertaubat, taubat menurut istilah para sufi adalah kembali kepada ketaatan dari perbuatan maksiat, kembali dari nafsu kepada haq (jalan kebenaran). Sebagaimana firman Allah dalam al-Qur'an surah al-Furqan ayat 70 dan 71, yang berbunyi: 
Kecuali orang-orang yang bertaubat dan mengerjakan kebajikan, maka kejahatan mereka diganti Allah dengan kebaikan. Allah maha pengampun, maha penyayang. Dan barang siapa bertaubat dan mengerjakan kebajikan, maka sesungguhnya dia bertaubat kepada Allah dengan tobat yang sebenar-benarnya. ${ }^{29}$

Dari firman Allah tersebut terlihat jelas bahwa seluruh perbuatan dosa yang telah dilakukan oleh hambanya, Allah pasti akan mengampuni dosanya kecuali bila dia menyekutukan Allah, mengenai remisi yang diberikan kepada pelaku tindak pidana narkotika di lembaga pemasyarakatan Sidoarjo, remisi diberikan bila narapidana telah berkelakuan baik atau telah bertaubat, dan juga telah menjalani masa pidananya selama 6 bulan, di mana dalam masa 6 bulan tersebut narapidana narkotika diberikan kesempatan untuk bertaubat atau untuk menyesali segala perbuatannya, jadi bila sudah berkelakuan baik maka ia sudah pantas diberikan haknya.

Pemaafan ataupun pengampunan dalam Islam khususnya dalam tindak pidana narkotika merupakan salah satu faktor pengurungan hukuman, baik diberikan oleh wali korban atau oleh penguasa negara. Disini terlihat jelas bahwa syarat pemberian remisi dalam hukum positif dan hukum pidana Islam memiliki kesamaan yaitu sama-sama mempunyai syarat bahwa pelaku tindak pidana narkotika harus berkelakuan baik atau bertaubat terlebih dahulu baru mendapatkan pemaafan atau keringanan hukuman berupa remisi. Jadi remisi ini diberikan di lembaga pemasyarakatan Sidoarjo untuk memenuhi hak-hak narapidana yang telah memenuhi syarat dan dalam hukum pidana Islam bisa dikatan juga remisi mengandung mashlahah mursalah yaitu sesuatu yang dipandang baik oleh akal, sejalan dengan tujuan syara' dalam menetapkan hukum namun tidak ada petunjuk syara' yang memperhitungkannya dan tidak adapula petunjuk syara' yang menolaknya.

\section{Simpulan}

Di Lembaga Pemasyarakatan Sidoarjo remisi diberikan dengan beragam, yaitu remisi umum, remisi khusus, remisi tambahan dan juga remisi dasawarsa. Remisi umum diberikan kepada pelaku tindak pidana narkotika pada hari kemerdekaan Indonesia, remisi khusus diberikan kepada pelaku tindak pidana narkotika pada hari keagamaan narapidana narkotika, remisi tambahan diberikan kepada pelaku tindak pidana

\footnotetext{
${ }^{29}$ Departemen Agama RI, Al-Qur'an dan Terjemahnya..., 511.
} 
narkotika yang telah menjadi pemuka dan selalu membantu kegiatan Lembaga Pemasyarakatan, dan remisi dasawarsa diberikan kepada pelaku tindak pidana narkotika selama 10 tahun sekali.

Remisi diumumkan pada tanggal 17 agustus pada saat upacara kemerdekaan di pendopo Sidoarjo, dengan cara mengumukan remisi seperti itu para narapidan tidak bisa mengetahui bahwa mereka telah menerima remisi atau tidak. Remisi diberikan yaitu sebagai hak para narapidana narkotika.

Narkotika banyak disebut dengan jarîmah hudûd dikarenakan mempunyai kesamaan illat dengan khamr, namun menurut penulis tindak pidana narkotika merupakan jarîmah ta'zîr di karenakan narkotika mempunyai efek yang lebih berbahaya dan lebih banyak madharatnya, narkotika bisa merusak masa depan seorang anak.

\section{Daftar Rujukan}

Ali, Zainuddin. Hukum Pidana Islam. Jakarta: Sinar Grafika, 2012. Awdah, Abdul Qadir. Ensiklopedia Hukum Pidana Islam. (Ahsin Sakho Muhammad dkk), Jilid III. Jakarta: PT Kharisma Ilmu, 2008. Al-Amruzi, M. Fahmi. "Analisis Hukum Pemberian Remisi Terhadap Pelaku Tindak Pidana”. Jurnal Darussalam, 2 Desember 2014. Arif, Hakim M. Bahaya Narkoba Alkohol. Bandung: Nuansa, 2004. Djazuli, A. Fiqh Jinayah (Upaya Menanggulangi Kejahatan dalam Islam). Jakarta: PT Raja Grafindo Persada, 2000.

Faried, Ahmad. Menyucikan Jiwa. Surabaya: Risalah Gusti, 2004. Farid, Ahmad. Taubat dalam Dosa. Jakarta: Amzah, 2006.

Hakim, Rahmat. Hukum Pidana Islam (fiqih Jinayah). Bandung: Pustaka Setia, 2000.

Irfan, Nurul. dan Masyarofah. Fiqh Jinayah. Jakarta: Pena Grafika, 2013. Marwan, M. dan P Jimmy. Kamus Hukum. Surabaya: Reality Publisher, 2009.

Munajat, Makhrus. Dekonstruksi Hukum Pidana Islam. Jogjakarta: Logung Pustaka, 2004.

Septiawadi. “Tafsir Sufistik tentang Taubat dalam Al-Qur'an”. Jurnal Studi Agama dan Pemikiran Islam. 2 Desember, 2013.

Thohir, Muhammad. "Tinjauan Hukum Pidana Islam Terhadap Pemberian Remisi Kepada Pelaku Tindak Pidana Pembunuhan 
(Studi Analisis Keppres Nomor 174 Tahun 1999)”. Fakultas Syariah Institut Agama Islam Negeri Walisongo Semarang, 2012.

Waluyo, Bambang. Pidana dan Pemidanaan. Jakarta: Sinar Grafika, 2000 Muslich, Ahmad Wardi. Pengantar dan Asas Hukum Pidana Islam. Jakarta: Sinar Grafika, 2004.

Departemen Agama RI. Al-Qur'an dan Terjemahnya. Jakarta: CV. Pustaka Agung Harapan, 2006.

Keputusan Presiden Nomor 174 Tahun 1999 tentang Remisi.

Keputusan Menteri Hukum dan Perundang-Undangan

No.M.09.HN.02.01 Tahun 1999 tentang Pelaksanaan Keputusan Presiden No.174 Tahun 1999.

Peraturan Menteri Nomor 21 Tahun 2013 tentang Syarat dan Tata Cara Pemberian Remisi, Asimilasi, Cuti Mengunjungi Keluarga, Pembebasan Bersyarat, Cuti Menjelang Bebas dan Cuti bersyarat.

Peraturan Pemerintah Republik Indonesia Nomor 28 Tahun 2006 tentang Syarat dan Tata Cara Pelaksanaan Hak Warga Binaan Pemasyarakatan.

Tim Penyusun Kamus Pusat Bahasa. Kamus Besar Bahasa Indonesia. Jakarta: Balai Pustaka, 2005.

Undang-undang Nomor 35 Tahun 2009 tentang Narkotika. 